\title{
Psychological Well-Being Dynamics of Catholic Pastors in Surabaya
}

\author{
Bartolomeus Yofana Adiwena, Khanis Suvianita, and Hartanti \\ Faculty of Psychology \\ Universitas Surabaya
}

\begin{abstract}
Being a pastor is a challenging life calling, not only in terms of duties and responsibilities, but also due to the lifestyle "demands". On a personal level, a pastor is an individual who still needs to take care of their own welfare as well as being cared for. The current study is a qualitative research that aims to understand the psychological well-being dynamics of pastors. There are two informants in this study. Results showed that factors supporting the psychological well-being of the two pastors are self-determination, skill and positive values acquired from the seminary, adaptive coping strategies, and social support.
\end{abstract}

Keywords: psychological well-being, pastor, self-determination, coping, social support

\begin{abstract}
Menjadi seorang pastor adalah sebuah panggilan hidup yang penuh tantangan, bukan hanya dari sisi tugas atau tanggung jawab yang dimilikinya, namun juga dari "tuntutan" gaya hidup yang harus dijalaninya. Secara pribadi, seorang pastor tetaplah individu yang perlu memerhatikan/diperhatikan kesejahteraannya. Penelitian ini merupakan penelitian kualitatif yang bertujuan memperoleh pemahaman mendalam tentang dinamika kesejahteraan psikologi (psychological well-being) pada para pastor. Informan dalam penelitian ini berjumlah dua orang. Hasil penelitian mengungkap bahwa unsur-unsur yang mendukung pencapaian kesejahteraan psikologi pada diri para pastor adalah determinasi diri kedua pastor informan, keterampilan dan nilai positif yang diperoleh di seminari dan mendukung mereka saat menjadi pastor, strategi penanggulangan (coping) yang adaptif, dan dukungan sosial yang dimiliki.
\end{abstract}

Kata kunci: kesejahteraan psikologi, pastor, determinasi diri, penanggulangan, dukungan sosial

Being a pastor is a profession that is known by the public as a religious leader in a Catholic church. As a pastor, the main duty is to give out sacraments to the people. Such sacraments cannot be done by those who are not ordained as a pastor. Aside for sacramental services, there are other duties such as being a church or organizational administrator, lecturer, counselor, or leaders in prayer. In some events, pastors are often the first choice of people to consult or ask advice from for personal or family matters (Weaver, Larson, Flannelly, Stapleton, \& Koenig, 2002).

For the pastor monk, they have to utter the vows of poverty, obedience, and purity before becoming a pastor. The vows of poverty were uttered during the ordaining ceremony to help them maintain a simple, non-hedonistic lifestyle. From the vow of obedience,

Correspondence concerning this article should be addressed to Bartolomeus Yofana Adiwena, Faculty of Psychology Universitas Surabaya, Jalan Raya Rungkut Mejoyo, Surabaya 60293.E-mail: Adiwena.tik@gmail.com a pastor is required to abandon his ego to be obedient to rules or congregation constitution, as well as superiors (congregation leaders or bishop). From the purity vow, they are determined to pursue holiness and devote their entire life to God and the people without being bound to marriage or family. These vows distinguish the life of a pastor from the life of people in general.

The urban lifestyle is identical with progress and luxury as seen by complete facilities, shopping centers and entertainment that are ever-growing, the highly varying socioeconomic status of the people, and social problems that become increasingly complex. The life of pastors in Surabaya cannot be separated from the urban context that will affect aspects of their own life as well. Aside from being related with their lifestyle, the higher complexity of problems faced by city dwellers requires pastors to administer more attention for those problems. 
"You need to be pastors who serve, who is humble, and prays. These things are not easy in the age of consumerism, hedonism, pop culture that worships material things. People should also pray for new and existing pastors to help them keep faithful until the end. This is to help them be loyal to their faith as well." (Speech by Mgr. Ignatius Suharyo, bishop of Semarang at the time in an ordinance ceremony of twelve pastors in Surabaya on August 30, 2006)

From this explanation, it can be seen that pastors have a great responsibility for the spiritual life of Catholics, especially those in the pastor's area of service. Such responsibility is related with the greater physical and psychological risks, such as tiredness and fatigue (Maslach, Schaufeli, \& Leiter, as cited in Isacco, Sahker, Krinock, Sim, \& Hamilton, 2015). Doolittle (cited in Isacco et al., 2015) also found data showing the increased level of burnout and distress in pastors. In his research, Charlton (cited in Barnard \& Curry, 2012) found that many pastors hide their burnout and maintain their positive public persona, because they believe that their job is a calling and thus they need to be able to cope with distress. In some cases, such fatigue is exacerbated by high expectations from the congregation and people and the low appreciation for their performance (Francis et al., cited in Barnard \& Curry, 2012). The two informants in this study sometimes experience burnout that they refer to as "drought".

"There are also personal matters. There are times when we feel some sort of drought, in a sense that our activities are so monotonous and we feel a sense of tiredness." (Interview with Pastor Andi, 38 years old)

"In some periods we will experience drought, and I experienced that. But in the end I need to do it, I realize that I am experiencing a drought, no motivation, tired. In the end I serve but only as a duty. You can say there is no spirit in us." (Interview with Pastor Beni, 46 years old)

Psychological well-being can be defined as how much a person feels good and fully functions (Ryan \& Deci, 2001). Psychological well-being is not about life being always positive. Individuals do not need to feel happy. Other negative emotions (disappointment, failure, sadness) are a normal part of life, and the ability to manage those emotions is important for an individual's psychological well-being. This is in accordance with the eudemonic principle that well-being will be achieved when individuals live their life with meaning and goal, and is useful for their own growth and other people's well-being. This principle is the basic topic of psychological well-being.

Similar to individuals in general, the psychologycal well-being of pastors is important. Many studies have shown that people with good psychological well-being will get many benefits in his/her life which includes increased performance, good social relationship, and even increased physical health (Huppert, 2009). Keyes (cited in Huppert) said that individuals with low psychological well-being have a greater risk for distress, depression, cardiovascular diseases compared to those with high psychological wellbeing. Individuals with high psychological well-being will feel capable, supported, satisfied with life, and optimistic (Huppert). With such a characteristic life pattern and responsibilities, psychological wellbeing is important for pastors. Therefore, the authors want to understand the psychological well-being dynamics of pastors so they can maintain a good level of psychological well-being and also their loyalty as a pastor.

\section{Method}

This study used a qualitative approach. Studies on the psychological well-being dynamics of pastors will be more relevant using a qualitative approach because it enables authors to be open to findings, so they can achieve deeper, better, and more meaningful results. The technique of sampling is a purposive sampling, so that the informants obtained are appropriate considering the context of the researched phenomenon (Poerwandari, 2005). The criterion set by the researcher is a pastor who only serves in a parish, not a pastor who has other duties as educators or administrators. This is so that the study can be focused on the psychological well-being of pastors related to their main duty of serving the people, not distracted by other work burdens in their other workplace(s). In this study, the researcher conducted in-depth interviews on two pastors who live and work in Surabaya (Pastor Andi and Pastor Beni). The data collection methods that were used were interview and observation.

The author(s) initiated the coding and data analysis stage by deciding the texts and information that are relevant with the research topic. The relevant text is then categorized into themes. These themes were then grouped into theoretical constructs and then analyzed. These theoretical constructs were link- 
ed and compared to reveal relationship patterns that were used to explain and understand the phenolmenon.

\section{Results and Discussion}

Achieving well-being is not an instant process, and thus this study collected information related to the initial want to be a pastor in childhood, educational years in the seminary, and post-ordination period.

\section{Building the Dream to be a Pastor}

The desire to be a pastor is very much influenced by the home environment of both informants. Andi lived in a village where most of the villagers were Catholics. Such uniformity and cohesiveness increased the appreciation of Catholic values by the villagers, including Andi. The people were actively involved in weekly religious routines such as going to the chapel on Sundays, and conducting prayers in the family. This Catholic majority created strong religious values for people living in the village, including Andi.

Unlike Andi, whose village consisted of mostly Catholic people, Beni's village consists of both $\mathrm{Ca}$ tholics and Muslims.

"And life there, one interesting tolerance that I see as interesting is that the two religions actually work together. This means for example in the construction of a prayer building, we take turns, as a group." (Interview of Pastor Beni, 46 years old)

The plural environment gave a positive impact on Beni. For him, life in diversity is normal and should not be challenged. In addition, such condition made everyone -including him- try their best to show their own religious identity without discrediting others' religious identity.

"That condition finally, (made) each of us show our own identity. At least physically they live out and celebrate prayer, for example. Each one goes to church on Sunday, on Friday to the mosque. When you don't see them on either Sundays or Fridays, people usually ask "What is your religion?" This side-by-side living also pushes us to be loyal to our faiths." (Interview of Pastor Beni, 46 years old)

Memorable experience during elementary school also nurtured the informant's desire to be a pastor. They see pastors and nuns who came to their village to serve as an interesting event.

"Back then, the pastors who served were Europeans. They came with bread, candies, shared with children (in the village). So that became the motivation. So as a child we thought: Being a pastor, you surely will eat good food. So that's the motivation back when I was a child." (Interview of Pastor Andi, 38 years old)

"In junior high school, we also have visitations from nuns and seminarians. Their arrival is very interesting. Full of joy and happiness. They blend very well with a lot of different groups: parents, children. That attracted me." (Interview of Pastor Beni, 46 years old)

Bandura, through his sociocognitive theory, explained the importance of observing and imitating behavior, attitude, and reaction of others or a model (Feist \& Feist, 2009). A majority of the learning process of an individual was done through observing model behavior in a social context. Andi and Beni did a modelling process on seminarians and nuns who served in their village. The positive experience told by these people about their life as well as the warm regards given by the people to the pastors became some sort of vicarious experience for Andi and Beni.

The next motivating factor stated by both pastor informants is the nurturing of faith values in the family and seminary, praying habits, and their own involvement in numerous religious activities, especially as an acolyte (usually young people, who are responsible to help pastors in a mass).

"Moreover, we need to live as faithful individuals. We are thoroughly Catholic, so in the environment, the village is $100 \%$ Catholic, so being religious is highly encouraged by the parents." (Interview of Pastor Andi, 38 years old)

"When we were little, I was a diligent acolyte. As an acolyte. Then pastor visits happen monthly, and there we also had roles as acolytes." (Interview of Pastor Beni, 46 years old)

Praying habits in the family, environment, seminary, and active involvement in religious ceremonies as acolytes enabled them to be very familiar with the church life and the sacrament. This familiarity created a positive emotion or love towards hierarchy and church life on both informants fitting the Mere Exposure Theory (first examined by Zajonc in 1968), which stated that someone who is intensevely exposed to or are in prolonged contact with a stimulus will slowly create positive emotion towards the stimulus, while at the same time reducing negative emotions related to the stimulus (Harmon-Jones 
\& Allen, 2001). This positive emotion on church life, faith, and sacrament strengthened the determination to become part of the Church hierarchy, in other words being a pastor.

One major point in the dream to becoming a pastor for both informants was that they were not forced by their parents to be a pastor. Being a pastor is not a construct that is shaped by parents to satisfy their own needs, but it is a dream constructed independently from the two informants' own experience. From Andi, maybe his mother and sibling gave "a slight push" to become a pastor, but that push is not forced and the last decision is still in Andi's hand. Beni's parent even did not give any ambition for their son to be a pastor, everything comes back to Beni.

"The family is very supportive. Supportive one hundred percent. And why they support: The decision is up to you, they mean up to me. We are supportive, but in the end you will be doing it. Or mother said that the child will be doing it." (Interview of Pastor Andi, 38 years old)

"Family, they are supportive in principle. They are not fanatically pushing me to be a priest. They said that what you choose, you need to be responsible for." (Interview of Pastor Beni, 46 years old)

Family also provided the opportunity for both pastors to freely choose their lifestyle. This acted as an important factor for their motivation as well as psychological well-being from the moment they start out, up until they become pastors. Openness and freedom to choose gave Andi and Beni space to carry out their choice based on their autonomous/ intrinsic motivation. Many topics on motivation showed that intrinsic motivation, which is an element of self determination, has a positive effect on someone's psychological well-being (Vallerand, cited in Deci \& Ryan, 2000; Deci \& Ryan, 2008; Visser, 2010). Conducting an activity based on intrinsic motivation-not out of force-can increase pride and self actualization which is an indicator of someone's psychological well-being (Ryan \& Deci, 2000).

\section{The Seminary as a Preparation for Prospective Pastors}

The seminary has an important role on providing adequate skills and knowledge for prospective pastors. In the Pastores Dabo Vobis (meaning "I Will Provide You a Shepherd") is a Catholic Church document released on March 25th 1992 by the late Pope John Paul II. This document discusses topics related to the formation of pastors and is aimed for pastors and general audience in the Catholic Church) document sent out by Pope John Paul II, it was stated that the creation of pastors in seminaries need to be based on four pillars: which are humanistic, spiritual, intellectual, and pastoral (Saint Charles Borromeo Seminary, 2015). In creating humanistic pastors, seminary members are educated to have integrity, an open personality, willingness to serve and care, respect to others, and becoming a confident leader. On a spiritual side, the pattern of care in the seminary needs to highlight prayer and meditation that has an important role in nurturing the spiritual side of pastors. On the intellectual side of pastors, seminary members obtained knowledge about religion and theological philosophy; they also get other knowledge and skills according to their interest and abilities. In a pastoral side, seminary members are trained and accustomed to doing services in parishes and other fields.

The seminary also applied a high level of discipline to shape the personality of seminary members that support their service when they become pastors. Discipline does not always involve restraining the freedom or movement of both pastors. Through discipline, they are trained early on in their life to become an individual with integrity and future maturity (Nieman \& Shea, 2004). Cooperation in community life also trained care and respect for others.

"And indeed we feel the benefit. If we just want to live according to our own needs, I'm not sure what we will be. But with discipline, living with regulations, then our character, personality, and mentality will be formed." (Interview of Pastor Andi, 38 years old)

Aside from upholding disciple, personality training on seminary members was also done through a special program. Both potential pastors received the opportunity to be trained individually and as a group. In a group session, they were trained on life ethics such as table manners, appropriate clothing, visitation regulations, and communication. These were done to prepare their life in the society with an approach and ethical standards that are acceptable by people in the society. Individual education was also provided in the form of counseling or consultation regarding life in the seminary or their life journey.

"Then there were days when we received group training for personality. Everyone had the chance to get individual training as well. If we have time to meet our mentors, they dig out our motivation to be a priest. We are helped to increase our motivation." (Interview of Pastor Beni, 46 years old) 
All training and development sessions in the seminary aims to form an appropriate personality for pastors, to have respect and care, and adequate intellect and spirituality. The formation period in the seminary trained members to be able to understand and accept their own self, and build numerous positive relationships with everyone, not just other seminary members. The values of respect and duty of care they possess became a requirement for their future life as a pastor, which is service or in psychological terms is called prosocial behavior. Indirectly, seminaries created within them a personality that is open to others and challenges, willing to serve, optimistic, caring, and respectful. Such personality traits were strongly related with positive emotional style and the achievement of psychological well-being (Huppert, 2009).

Education in the seminary is not merely regarding a number of knowledge and values, but also practical skills. Such skills include training on pastoral programs, cathecism, constructing preaching sessions, and answering people's questions. With the knowledge and skills, it was hoped that prospective pastors were well prepared to face the many challenges in their future life as a pastor, increasing the self respect and optimism, so none of the challenges pose as obstacles to achieving wellbeing.

\section{Becoming a Pastor: Challenges and Coping Strategy}

The first challenge faced by both pastor informants following ordination was adapting to the culture of their place of service. Initially they were shocked and uncomfortable due to how different the area was compared to their home. However, they did not despair; they instead were motivated to keep studying, adapting, and knowing local people to a point where they feel comfortable at the new place and were reluctant to leave it when they had to relocate to Surabaya. Surabaya is a major city that gave no guarantee for the pastors to have an easier time adapting to it. They have to adapt to the critical behavior and complexity of societal issues. There were sometimes little frictions with some people due to the people's lack of commitment.

"When wanting something, yeah. It is sad to say yes to something that I thought should be like that, but I feel uneasy if I say no. How this came to be, it made me sad. Or if we have promised to meet or to rehearse, or about marriage arrange- ment, we promised to meet at a certain time but they were late. It's useless to be angry. So I just kept it in." (Interview of Pastor Andi, 38 years old) "In the service, the problems are usually togetherness with the people, in this case with leaders of the council. Often we have joint commitments but in the end I was the only one to carry it out. There is a parish council, but in the end the pastor executed everything himself. This was what I experienced as a challenge in my service. That in their busy life they cannot manifest as one participative Church. Because in the church life, it needed to be participative. When a pastor is relocating, they will stay. So they indeed need to be involved." (Interview of Pastor Beni, 46 years old) In leading a parish, pastors are assisted with the parish council. The existence of such council helped pastors to make decisions, but sometimes the pastors then have to make an unwanted decision. Compromising with the decision making process, this experience posed as a unique challenge for the pastors.

"Sometimes we need to acknowledge that we meet people who are difficult to communicate with. They want to force their own will; it needs to be like this and this, pastor. We are faced with a variety of people. When we make a decision, it is not our own but the council's, then there are those who accept it, those who don't, those who complain, so there's a lot of things." (Interview of Pastor Andi, 38 years old)

"When becoming head pastor, we need to make decisions and there are some decisions that we dislike but we have to make. For example, in terms of employees. I have to let him go, but my heart asks how he will be in the future. I have also given him numerous warnings, so as a pastor I have to be strict and fire him. And this makes me feel uneasy, but I still have to make the decision. And as a head pastor, it is indeed with a council, but the final decision needs to have a confirmation." (Interview of Pastor Beni, 46 years old)

Personal daily routine of pastors create a sense of boredom for the pastors. Tiredness and lack of passion are consequences of doing the same thing every day. Such things make them lack focus in their service. Sometimes, activities are done only as a responsibility, and not based on the spirit of service.

"There are also personal matters, and when we feel like in a drought. This means that our activity is really monotonous and repetitive that we feel bored." (Interview of Pastor Andi, 38 years old) "In some periods we will experience drought, and 
I experienced that. But in the end I need to do it, I realize that I am experiencing a drought, no motivation, tired. In the end I serve but only as a duty. You can say there is no spirit in us." (Interview with Pastor Beni, 46 years old)

When adapting with relocation to Surabaya, both pastors utilized problem-focused coping, but with different focus. When allocated to Surabaya, pastor Andi realized that Surabaya is a metropolitan city with complex problems and better quality human resources compared to his previous area of service in North Sumatra. This motivated him to keep studying so that he can give better sermons and to better answer the people with regards to their curiosity regarding the Catholic faith. On the other hand, Pastor Beni focused more on becoming familiar with the situation and condition of Surabayan people. This was done so that he can give services and programs that are appropriate to the people's needs.

"Initially, I thought that city people certainly have a better general knowledge compared to regional people, in the village. This motivated me to study even more, because people pose questions that are complex and never ending. For example after homily they asked "pastor, we heard you say such and such, what does this book mean?". In the village, after the homily is done, that's it. Or the pastor did catechism, afterwards no one asked questions. But here, a lot of people want to ask questions. From there, the knowledge of city people are different to village people, and so when I was tasked to move here I thought it was a blessing because I am forced to study. Studying lasts forever, after all." "In some periods we will experience drought, and I experienced that. But in the end I need to do it, I realize that I am experiencing a drought, no motivation, tired. In the end I serve but only as a duty. You can say there is no spirit in us." (Interview with Pastor Andi, 38 years old) "As a first step, hmm I have to know the Javanese culture, and then the city culture. The Javanese culture, in Surabaya it is not Java-dominant but more urban-dominant where there is pluralism. Oh city culture is like that. So first I have to build communication with the pastoral council. And that becomes a work team. So firstly I listened to my council. How is the situation. And they give us a new reality. If they find a reality then I try to listen from others, from pastoral colleagues in Surabaya, especially SVD. And then I try to listen what is specific here. Then I do family visits, not to look at issues but merely to introduce myself as a new pastor and hear out their situations. From there I compare with what was shared by the council. And from there I can have a better understanding of the situation." (Interview with Pastor Beni, 46 years old)

Even if it was done differently, the adaptation process of both pastors reflects their ability to control their experienced situation to not let it be a pressure (Maddi, 2013). Things that are experienced are considered a challenge for self-improvement and to help them give better service.

Amidst the amount of activities, taking a break from daily routine to refresh the mind is beneficial to do. Although done in a short period of time, refreshing can bring back the spirit and motivation for pastors. Both pastor informants do similar activities. In certain times of the day, they refresh themselves by taking a walk, reading a book, or doing other hobbies. Surabayan diocese stated that pastors in Surabaya should have holidays on Mondays. Pastors are also given two weeks annual leave. During this leave, both pastors usually visit their family back home.

"It is human that we need rest. So when the phone rings we let it ring. When we wake up we can then ask what do they need. (Now) we can leave it be. It is time to replenish our energy. Refreshing is going for a walk around Surabaya, or to the mall. That's it." (Interview with Pastor Andi, 38 years old)

"On Mondays, pastors get the chance to take care of their personal matters. He can research, read, and reflect. Every Monday, pastors are given the opportunity to be free of service, in terms of consultation. He is given time to reflect, to read, on Mondays. And then spiritual reflection is done during refreshing periods in our holiday. For that, we can actually do it in the evening, past 10 o' clock we have time to read or do something." (Interview with Pastor Beni, 46 years old)

Pastors also have a number of agendas that are done together for self-improvement and refreshment purposes. The diocese runs annual retreat that is attended by all pastors in Surabayan diocese. In the event, all pastors reflect his journey together, support each other, and construct programs that will be done together. Additionally, there is also a study day where pastors can improve their intellectual capability. In that study day, pastors attend selected seminars given by experts, or create research.

As the leader of the people, the people certainly have big expectations for the pastor. Numerous de- 
mands come from the people expecting pastors to create certain programs, behave, or serve according to the needs of the people. Considering the sheer amount of people that can even reach thousands, the pastors are obviously not capable to fulfill all the demands. Both pastors try to be themselves and to do their job according to the constitution of the church.

"Always be aware that I am this, and this is me. The people of 'A' demand that I need to do this, I need to be that, but I cannot. 'A' demands that I need to be like the other pastor. I cannot do that. It is like that. But I'm aware that this is me. I cannot be like another because he has the ability, he has the talent there." (Interview with Pastor Andi, 38 years old)

"As a leader I need to be able to be myself. I cannot live a life that my people wanted me to live. I can only be myself. I live being known as a pastor monk, and that is me. Obviously other people have this expectation and that expectation, but I cannot follow it. I can only be me. Everyone has different views. A good pastor according to ' $A$ ' is different from a good pastor according to 'B'. So I need to be myself. That's it." (Interview with Pastor Beni, 46 years old)

Both pastor informants do not fully ignore the demands of the people. If those demands are objective and constructive to the quality of service and spiritual lives of people, they will gladly accept the suggestion. Both pastor informants also do not place too much of an expectation on the people. For them, the most important thing is to do their job as best as they can, whether it is effective or not or whether the change to people's behavior is significant is not their focus; at least they have done their best. Indirectly, the choice to be true to oneself and to not push their view on others is a coping strategy that made both pastors capable of avoiding troubles, being pressured by future demands, or frustrated because their goal is not achieved. Such strategy can be seen as problem-focused coping, which is solving problems and challenges by doing constructive activities (for more details, see Taylor, 2015 or Weiten, 2014).

Prayer is something that cannot be left by pastors as an ecclesiast. Prayer becomes a source of strength and motivation, and also becomes an emotion-focused coping strategy done by both pastor informants to face all the challenges they encounter. Through prayer, they obtained a sense of control and comfort in facing problems that they feel are too tough and outside of their ability. Prayer gives strength and spi- rit to deal with issues (Paraschiva \& Nicoleta, 2011). Indirectly, prayer becomes a unique source of strength for them.

"I cannot describe how great God is, only when I pray, ask, and plead. But prayer for me is not just asking, but praising Him, giving thanks, and pleading. These three things is a complete package in my prayer. Praising Him, greeting Him, being thankful, and then asking. And it is very wonderful." (Interview with Pastor Andi, 38 years old) "Prayer for me is an... effort to communicate. Communicating with God Himself. I say what I understand, what I felt, and what I need. Prayer is a communication between me and God. I say how I serve and what I need." (Interview with Pastor Beni, 46 years old)

Both coping strategies are adaptive when used in the appropriate situation. Situations that with a challenge that is solvable are best addressed with problem-focused coping, whereas situations that can only be accepted and is outside of an individual's control is best approached with emotion-focused coping (Taylor, 2015). In facing daily challenges, both pastors use both strategies appropriately. So they can address or reduce the negative impact of highpressure conditions.

Both pastor informants also showed hardiness in daily challenges. Hardiness is a factor that influences a person's tolerance towards pressure (Weiten \& Lloyd, 2006). (For more details see Maddi (2013) especially chapters 1 and 2.) The challenges they face are seen as opportunities to keep studying and improving themselves. Both pastor informants also have a good control of the situation; no matter how big the problem is, they can solve it. They also have a commitment that this is their task with all its problems, and so they need to do it dutifully.

"But this is a choice. So even if I am faced with new situations, new people, new culture, and new language, I am motivated to learn and adapt with the people around me." (Interview of Pastor Andi, 38 years old)

"I just mentioned that by deciding to be a pastor I have considered them (challenges and problems), That when in the field, I have to be responsible for my commitment." (Interview of Pastor Beni, 46 years old)

Hardiness is a personal resource that affects the decision to choose a coping strategy to face challenges or pressures in daily life. A more positive level of hardiness tends to correlate with a more appropriate choice of adaptive coping strategy; in con- 
trast, low level of hardiness correlates with less appropriate choice of adaptive coping strategy (Hachaturova, 2013). With an adaptive coping strategy, challenges or obstacles that can cause distress can be addressed effectively. The ability to control stress supports a person's effort to achieve a state of well-being (Taylor, 2015). In other words, the hardiness of both pastor informants supports them in dealing with many challenges and problems, to a point where both are able to achieve well-being.

\section{Am Never Alone: Receiving Social Support}

Social support is an important aspect that helps pastors in their activities. Social support can be about giving room or opportunity for individuals to choose, or support in terms of giving motivation and suggestion for an individual to increase their self determination. The question that arises is then how do they gain social support like families in general? The answer lies in their community (pastors). In the community life, they experience that they are part of a small family. There's allocation of responsibility, a rule that needs to be obeyed together, and there is affection or supporting each other that is given by fellow pastors in the community.

As a pastor monk, community life is very important. As an SVD, service done in any place is usually done with another pastor, to a minimum of two pastors. The community is a family for pastors in their area of service. With a service area located far away from home, the presence of colleague in the community is the "closest family member" for a pastor to share and support each other amidst the number of challenges they have to face. The community becomes a source of strength in their life as a pastor.

"The relationship with other pastors is supportive. Supporting others in our service. Sharing opportunities. The things that I cannot do in our service, I ask a friend to do it. In essence, it's cooperation. We try to cooperate. If there's a request for service, others ask me "Eh..., I can't do it. Try other pastors. Or if you can't find another pastor, I will try and find an external pastor." So we try to coordinate each other's service duties." (Interview of Pastor Andi, 38 years old)

"So the benefit is the realization of service. Living together functions to make our service smoother. In addition, a community is where I build communication with colleague, a place to share, and to reflect my service. The place where I can reflect until I find a new source of power, and to see my limitations, and a community is a place where I reflect on all services. As a person of faith, we have to live in a community. A minimum of two people." (Interview of Pastor Beni, 46 years old)

Pastor Andi and Pastor Benny both stated that their life as a pastor did not make them completely abandon their family. For them, friends and family are actually very important in their calling as a person of faith; family is one source of their strength. They have experienced the support of their family starting from their seminary life, up until now when they have years of experience as a pastor.

The family continually supports, motivates, and prays for both pastor informants. Communication with the family can only be done through telephone, considering both pastors are in Surabaya while their family is in NTT. The parents and siblings of Pastor Andi routinely calls to ask him about how he is doing and to ask them to always take care of his health. For Pastor Beni, sometimes family members inform him of family situations or any other events as well as asking him to pray for them. Those simple things are actually very meaningful for both pastor informants. Communication that was built showed care and attention of the family for their own life.

"They always ask 'How are the people there?' I used to be tasked to Sumatra, in the village. Village people. Now they always ask: 'Are you okay with your duties and tasks in service, how is your people, how do they respond to you?' With such simple questions, I feel like it is a supportive notion, they want to know the response of the people, do they respond with happiness, openly accepting my presence as a pastor in my duties and services or how else. For them, that curiosity is a form of support. And in the end they say 'Serving the people, don't forget to take care of your health.' That's what I really feel, how great the amount of attention from older siblings. It is good to serve others but don't forget yourself, in this case your health." (Interview of Pastor Andi, 38 years old)

"They asked how I was. I felt their attentiveness towards me. There is always attentiveness. How is it there. If there is no call for two or three weeks, they SMS me asking how I was doing." (Interview of Pastor Beni, 46 years old)

Support for both pastor informants also come from the people they serve. Such support is not always material in nature, but rather support in terms 
of attentiveness for the pastor is enough to make them happy as a pastor in the parish. Attentiveness also comes from the people during Pastor Andi's birthday or service commemoration. It is not uncommon for people to give surprises, as well as sending prayers and wishes to him. Such hopes give motivation for pastors to keep being faithful to his service.

"For me, there is nothing significant that shows their support. A simple thing, such as when meeting and greeting others is an extraordinary thing, there is mutual respect, acceptance: 'Oh this is my pastor.' So acceptance, support does not always mean I have to be invited to the person's home first, or to ask me out for a meal. It's not that. But we meet, greet each other, or passed 'Hey pastor, where are you going?' This means my people know me. It is a sign that they care for me, love me as their shepherd. Or in a crowded mall full of people, suddenly someone grabbed my shirt from behind: 'Where are you from?' that's when we are reminded personally that there is a sheep, there are people here who pay attention to me." (Interview of Pastor Andi, 38 years old)

Equally important for pastor Beni is support from the people shown by their willingness to cooperate in programs or services that are designed together. With such support, service can be done more optimally.

"And I as a pastor, where pastors are not single fighters but work as a team, and in a parish council they stay while pastors move around. So initially I have to be able to build communication with them. Afterwards, like I said, after hearing from the council I try to hear out from the pastors in Surabaya, and then in the people's environment, so there I experience that with the primary council I can work together." (Interview of Pastor Beni, 46 years old)

A number of social support received by pastor informants have become invaluable assets that they have. With social support, they never feel completely alone. Social support is an interaction process related to increasing coping, self-esteem, feeling of being loved, and competence through exchange of physical or psychosocial resources, whether they are actual or perceived (Gottlieb, cited in Mattson \& Hall, 2011). Social support enables individuals to be more certain and more in control of the situation faced by them, so feelings of threat can be reduced and can support individuals to achieve well-being (Weiten \& Lloyd, 2006).

\section{Still Being Loyal: Happiness and Hopes}

The joys and sorrows of being a pastor have been experienced by both informants; however that does not stop them from loving their life calling. Once ordained, they are committed to following their life choice as a pastor with all of its happiness and sadness. Their childhood dream is still something very special for. For them, being involved in God's work is something that makes them feel happy.

"The thing that makes me feel happy is because it is my choice. It is my initial commitment. Up to this day, I never regret my decision of being a pastor. I am still happy. Happy as a pastor, with all of its joys and sorrows." (Interview of Pastor Andi, 38 years old)

"Up until now I still enjoy my choice so wherever I am allocated to, even though it is difficult, I still enjoy it." (Interview of Pastor Beni, 46 years old) The love towards being a pastor as a profession is manifested from service that is optimal and comes from the heart to the people and others. They try to do their duties as best as they can. In his eighth year of ordination, Pastor Andi hopes to still be faithful to his calling and to be able to serve more people. With more people in his service, he hopes that more people will come to believe in God. Similar to Pastor Andi, Pastor Beni hopes to still be loyal to his service and calling as a pastor.

"My goal of being a pastor, my hope is for myself to serve as best as I can and still be committed to maintain my faith forever. That is my hope." (Interview of Pastor Andi, 38 years old)

"It is my hope to keep being a pastor in this case. I still serve in my call of duty as a pastor. My hope is supported with loyalty to do my tasks, loyalty to live in the community, loyalty in prayer, loyalty in cooperation with the parish council, and loyalty in the communication with the people." (Interview of Pastor Beni, 46 years old)

Looking at the eudaimonic viewpoint, well-being is not just being happy and having a materialistic life satisfaction. More than that, well-being is a situation obtained from the congruence or slice between activities that are done and personal values (Walterman, cited in Ryan \& Deci, 2001). Passion to servewith its happiness and sorrow-has been instilled within them and is a means to achieve well-being, and not an obstacle or threat to well-being. Service does not always occur smoothly every time, but various "assets" that the pastors have (self determination, knowledge and skill, coping strategy, and 


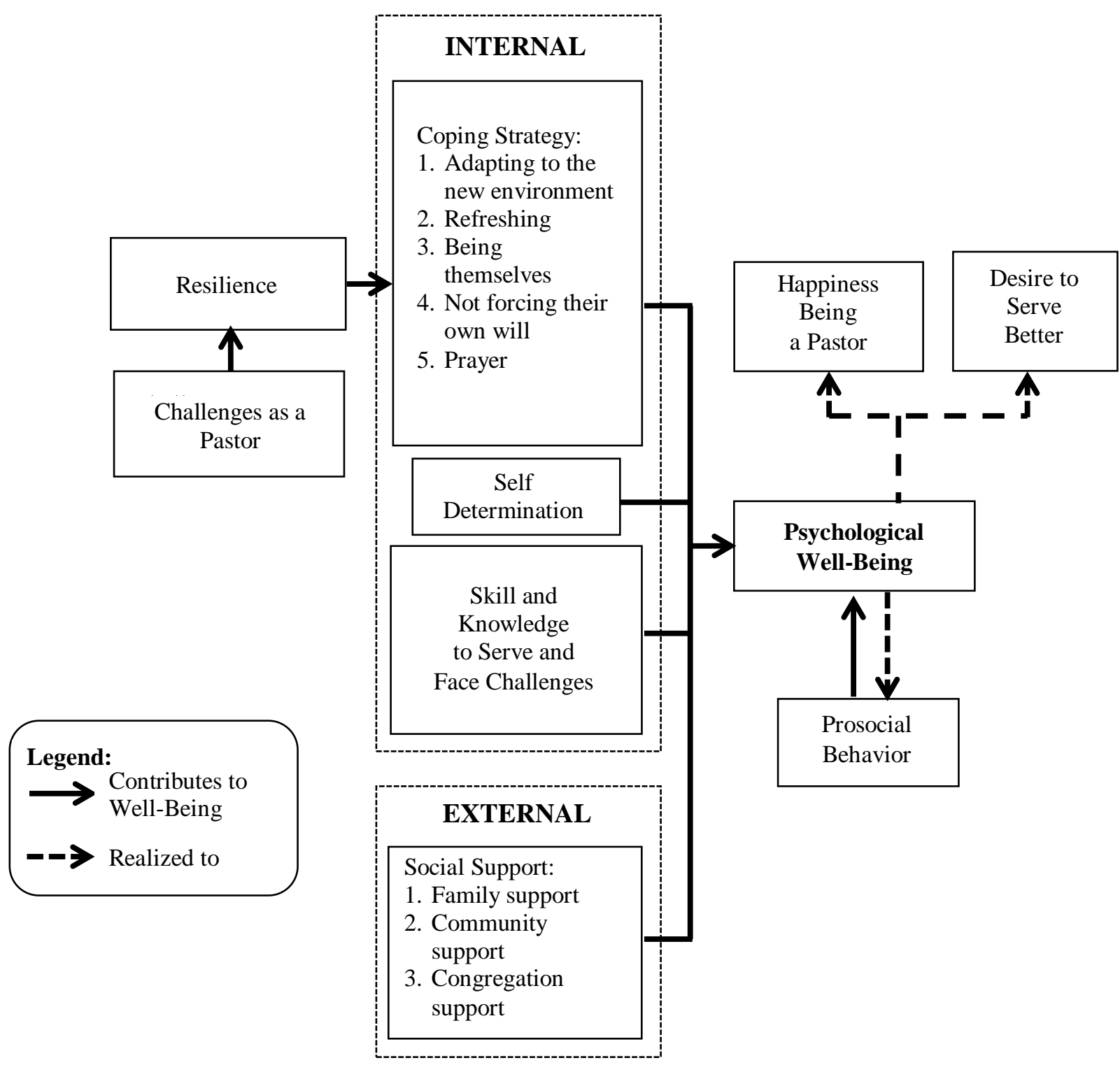

Figure 1. Psychological well-being dynamics experienced by both pastor informants.

social support) enables them to still try their best to achieve well-being.

\section{Limitation and Suggestion}

Both pastor informants showed positive attitude regarding their psychological well-being dynamics, that can be an indication of their social desirability, and that can be a threat to the credibility of this study. In addition, this study has given a number of important information for Catholic pastors that can guide future studies to increase their well-being.

From this research, the role of seminaries as the "birthplace" of pastors with good level of well-be- ing is revealed. Future research of value should focus on the process of formation in the seminary; regarding the values taught and the four pillars that become the mission of seminaries (creating humanistic, intellectual, spiritual, and pastoral individuals). Aside from focusing on the formation process in the seminary, future research should consider the role of the spirituality of the congregation on psychological well-being, or in other words research other informants from other congregations. Each congergation possesses different spirituality and motivation, and these have an effect on values that are taught, which possibly contributes to the achievement of well-being. 


\section{Conclusion}

This research also concluded that being a pastor does not prohibit both informants from achieving well-being. Indeed, it can even help people achieve well-being if being a pastor is really what they wanted. Strong self-determination to become a pastor, aided by a supportive environmental pattern, starting from parents' parenting style or school curriculum that highlights values of discipline, responsibility, and faith are assets obtained from a very early age. A number of skills and positive values taught in the seminary helped them when becoming a pastor (humanistic, intellectual, spiritual, and pastoral). Following ordination, an important thing to achieve well-being as an adaptive coping strategy due to hardiness and received social support. These are "assets" possessed by both pastor informants to become individuals with a good level of well-being.

\section{References}

Barnard, L. K., \& Curry, J. F. (2012). The relationship of clergy burnout to self-compassion and other personality dimensions. Pastoral Psychology, 61(2), 149-163.

Deci, E. L., \& Ryan, R. M. (2000). The "what" and "why" of goal pursuits: Human needs and the self-determination of behavior. Psychological Inquiry, 11(4), 227-268.

Deci, E. L., \& Ryan, R. M. (2008). Self-determination theory: A macrotheory of human motivation, development, and health. Canadian Psychology, 49(3), 182-185.

Feist, J., \& Feist, G. (2009). Theories of personality. New York: McGraw-Hill.

Hachaturova, M. R. (2013). Hardiness as a resource of personality's coping behaviour in difficult situations. Academic Journal of Interdisciplinary Studies, 2(8), 225-230.

Harmon-Jones, E., \& Allen, J. J. (2001). The role of affect in the mere exposure effect: Evidence from psychophysiological and individual differences approaches. Society for Personality and Social Psychology, 27(7), 889-898.

Huppert, F. A. (2009). Psychological well-being: Evidence regarding its causes and consequences. $A p$ plied Psychology: Health and Well-Being, 2, 137-164.
Isacco, A., Sahker, E., Krinock, E., Sim, W., \& Hamilton, D. (2015). How religious beliefs and practices influence the psychological health of $\mathrm{Ca}$ tholic priests. American Journal of Mens Health, SAGE Publications, Published online before print January 23, 2015, doi: 10.1177/1557988314567325

Maddi, S. R. (2013). Hardiness: Turning stressful circumstances into resilient growth. London: Springer.

Mattson, M., \& Hall, J. G. (2011). Health as communication nexus: A service-learning approach (1st ed.). Iowa: Kendall Hunt Publishing.

Nieman, P., \& Shea, S. (2004). Effective discipline for children. Paediatr Child Health, 9(1), 37-41.

Paraschiva, P., \& Nicoleta, M. (2011). Ways of approaching religiosity in psychological research. The Journal of International Social Research, 4 (18), 352-362.

Poerwandari, E. K. (2005). Pendekatan kualitatif untuk penelitian perilaku manusia. Jakarta: Lembaga Pengembangan Sarana Pengukuran dan Pendidikan Psikologi (LPSP3) Universitas Indonesia.

Ryan, R. M., \& Deci, E. L. (2000). Self-Determination Theory and the Facilitation of Intrinsic Motivation, Social Development, and Well-Being. American Psychologist Association, 55(1), 68-78.

Ryan, R. M., \& Deci, E. L. (2001). On happiness and human potentials: A review of research on hedonic and eudaimonic well-being. Annual Review of Psychology, 52, 141-166.

Saint Charles Borromeo Seminary. (2015). The four pillars of priestly formation. Retrieved from http:// www.scs.edu/four-pillars-priestly-formation

Taylor, S. E. (2015). Health psychology (9th ed.). New York: Mc Graw-Hill Inc.

Visser, C. F. (2010). Self-determination theory meets solution-focused change: Autonomy, competence and relatedness support in action. The Journal of Solution Focus in Organisations, II(1), 7-26.

Weaver, A. J., Larson, D. B., Flannelly, K. J., Stapleton, C. L., \& Koenig, H. G. (2002). Mental health issues among clergy and other religious professionals: A review of research. The Journal of Pastoral Care \& Counseling, 56(4), 393-403.

Weiten, W. (2014). Psychology: Themes and variations, briefer version (9th ed.). Belmont: Cengage Learning.

Weiten, W., \& Lloyd, M. A. (2006). Psychology applied to modern life: Adjustment in the 21st Century. Belmont: Thomson Learning. 